\title{
PENGARUH PENGGUNAAN MULTIMEDIA COMPUTER ASSISTANCE INSTRUCTION MODEL TUTORIAL PADA BAHASAN INTERAKSI DALAM EKOSISTEM TERHADAP HASIL BELAJAR SISWA DI KELAS VII SMP KARTINI 2 BATAM
}

\section{THE EFFECT OF MULTIMEDIA COMPUTER ASSISTANCE INSTRUCTION MODEL TUTORIAL USED ON THE DISCUSSION ON ECOSYSTEM INTERACTION TOWARD STUDENT LEARNING OUTCOMES AT CLASS VII SMP KARTINI 2 BATAM}

\author{
Juliana Saffitri ${ }^{1}$, Yarsi Efendi ${ }^{2}$, \\ ${ }^{12}$ Program Studi Pendidikan Biologi, FKIP, Universitas Riau Kepulauan, Batam \\ *Korespondensi :
}

\begin{abstract}
Abstrak
Tujuan dari penelitian ini adalah untuk mengetahui apakah ada pengaruh penggunaan multimedia computer assistance instruction model tutorial pada bahasan interaksi dalam ekosistem terhadap hasil belajar peserta didik kelas VII di SMP Kartini 2 Batam tahun ajaran 2013/2014. Sampel penelitian adalah seluruh siswa kelas VII sebanyak 60 siswa. Instrumen penelitian yang digunakan untuk mengumpulkan data yaitu kelas eksperimen dengan menggunaan multimedia computer assistance instruction model tutorial, sedangkan kelas kontrol tidak penggunaan multimedia computer assistance instruction model tutorial pada proses pembelajarannya. Kualitas instrumen dinilai berdasarkan uji validitas dan uji reliabilitas. Uji statistik yang digunakan untuk menguji hasil penelitian digunakan uji hipotesis dengan menggunakan rumus Uji-t.

Berdasarkan hasil analisis diperoleh uji hipotesis bahwa $t_{\text {hitung }}(2.19)>t_{\text {tabel }}(1.69)$, maka $\mathrm{H}_{0}$ ditolak dan $\mathrm{H}_{1}$ diterima sehingga disimpulkan bahwa penggunaan multimedia computer assistance instruction model tutorial dalam proses pembelajaran positip dapat meningkatkan hasil belajar peserta didik.
\end{abstract}

Kata Kunci : Multimedia Computer Assistance Instruction Model Tutorial, Ekosistem, Hasil Belajar Peserta Didik

\begin{abstract}
The purpose of this study was to determine whether there was any effects of the computer multimedia instruction models tutorial assistance used on ecosystem interaction discussion at class VII SMP Kartini 2 Batam Academic year 2013/2014. The samples were all students of class VII as totally as 60 students. The research instrument used to collect data from experimental class by using computer multimedia instruction models tutorial assistance, while the control or conventional class did not use a computer multimedia instruction models tutorial assistance on the learning process. Quality instrument rated based on test validity and reliability testing. The statistical test used to test the results of the research used hypothesis using t-test formula. Based on the analysis results obtained by testing the hypothesis that $T_{\text {counted }}(2.19)>T_{\text {tabel }}(1.69)$, then $H_{0}$ was rejected and $H_{1}$ was accepted thus concluded that the use of computer multimedia instruction models tutorial assistance in the learning process can positively improve the students learning outcome.
\end{abstract}


Keywords: Computer Multimedia Tutorial Assistance, Ecosystems Interaction, Learning Outcomes.

\section{PENDAHULUAN}

Salah satu komponen yang menentukan untuk terjadinya proses belajar adalah guru dan strategi mengajar yang digunakannya. Guru juga berperan dalam usaha pembentukan sumber daya manusia yang potensial. Oleh karena itu guru berperan aktif menempatkan kedudukan sebagai tenaga professional sesuai dengan tuntutan masyarakat yang semakin berkembang. Guru harus senantiasa menggunakan segala upaya termasuk menggunakan keterampilan yang dimilikinya, salah satu dari keterampilan itu adalah penggunaan media dalam pembelajaran saat mengajar.

Salah satu media pembelajaran yang berkembang saat ini adalah multimedia seperti video dan animasi. Program Computer Assistance Instruction model tutorial berisi materi yang berbentuk audio visual yang berisikan materi yang disampaikan oleh guru dengan menggunakan animasi dan suara untuk memperkuat penyampaian isi. Penggunaan program Computer Assistance Instruction model tutorial ini dapat diputar melalui komputer, VCD player, tablet bahkan smart phone yang hampir bisa dipastikan setiap peserta memiliki salah satu alat untuk memutarnya.

Berdasarkan cara penggunaan mudah dan portable (dapat digunakan dimana saja dan kapan saja) program Computer Assistance Instruction model tutorial dapat membantu guru dan peserta didik untuk tetap melaksanakan pembelajaran walau tak bertatap muka, sehingga tercapainya sistem belajar yang fleksibel sesuai dengan kehidupan dan gaya belajar peserta didik serta memaksimalkan peran guru sebagai fasilitator dalam proses belajar mengajar sehingga terjadinya aktivitas yang berpusat pada peserta.

Berdasarkan hasil observasi awal bahwa pembelajaran di SMP Kartini 2 Batam, lebih banyak berorientasi pada guru dengan media yang hanya terbatas pada presentasi power point atau dengan pembelajaran metode diskusi. Dengan metode yang berorientasi pada guru, mengakibatkan guru hanya fokus pada penyampaian materi, sehingga kemampuan penguasaan kelas dan interaksi fisiologis individu antara peserta didikdan guru kurang optimal. Sehingga banyak peserta didik merasa bosan dan mencari aktifitas sendiri seperti ribut bahkan tidur disaat proses pembelajaran. Begitu juga dengan metode diskusi dan tanya jawab, yang aktif hanya sebagian dari peserta didik, terutama untuk peserta didik yang duduk 
paling depan di kelasnya dan yang duduk paling belakang tidak termotivasi untuk mengikuti pelajaran.

\section{METODOLOGI}

Populasi yang digunakan dalam penelitian ini adalah seluruh peserta didik kelas VII SMP Kartini 2 Batam. Menurut Sugiyono (2013) sampel merupakan bagian dari jumlah karakteristik yang dimiliki oleh populasi tertentu. dalam penelitian ini akan diambil jumlah sampel sesuai dengan jumlah populasinya atau dinamakan sampling jenuh. sampling jenuh menurut Sugiyono (2009) sampling jenuh adalah teknik pengunpulan sampel bila semua anggota populasi digunakan sebagai sampel, hal ini sering dilakukan bila jumlah populasi relatif kecil, yaitu kurang dari 30 orang, atau penelitian yang ingin membuat generalisasi dengan kesalahan yang sangat kecil. istilah lainnya adalah sampel jenuh, dimana semua anggota populasi dijadikan sampel.

Data dalam penelitian ini adalah seluruh siswa dari kelas eksperimen dan kelas kontrol yaitu kelas VIIb sebagai kelas eksperimen dan VIIa sebagai kelas kontrol. Adapun datanya adalah data primer yang diperoleh dari skor hasil belajar siswa kelas VII SMP Kartini 2 Batam. Teknik analisis data menggunakan teknik analisis deskriptif dan analisis

inferensial, meliputi; a) Data yang dideskripsikan adalah hasil post test kelas eksperimen dan kelas kontrol. dengan menghitung rata-rata (mean), ragam (variansi), dan simpang baku (standar deviasi); b) data statitik inferensial yaitu: Uji normalitas yang digunakan adalah uji Liliefors. Langkah-langkah perhitungan uji normalitas data menggunakan uji Liliefors; Uji homogenitas dilakukan untuk melihat apakah kedua kelompok sampel mempunyai varians yang homogen atau tidak dengan menggunakan Uji-F; dan c) Uji Hipotesis menggunakan perbedaan rerata dua kelompok perlakuan dengan menggunakan uji t satu pihak.

\section{PEMBAHASAN}

Dari hasil analisis deskriptif kelas kontrol terlihat bahwa, dari 30 peserta didik di kelas VIIa, total nilai hasil yang diperoleh 2200. Nilai tertinggi yang diperoleh 90. Nilai terendah yang diperoleh 50. Nilai rata-rata diperoleh 73.33. Standar deeviasi yang diperoleh 8.54. Varians yang diperoleh 72.98. Median/nilai tengah yang diperoleh 75. Modus/nilai 
yang sering keluar 70. Adapun distribusi frekuensi data hasil belajar peserta didik di kelas kontrol dengan model pembelajaran konvensional ditampilkan pada Tabel 1.

Tabel 1. Distribusi Frekuensi Hasil Belajar Di Kelas Kontrol

\begin{tabular}{|c|c|c|c|c|c|c|}
\hline \multirow[b]{3}{*}{ NO } & \multicolumn{6}{|c|}{ REKAPITULASI FREKUENSI KELAS KONTROL } \\
\hline & \multicolumn{4}{|c|}{ BATAS NYATA } & \multicolumn{2}{|c|}{ FREKUENSI } \\
\hline & $\begin{array}{c}\text { KELAS } \\
\text { INTERVAL }\end{array}$ & BAWAH & ATAS & $\begin{array}{c}\text { NILAI } \\
\text { TENGAH }\end{array}$ & $\begin{array}{c}\text { ABSOLUT } \\
\text { (SISWA) }\end{array}$ & RELATIF (\%) \\
\hline 1 & $50-56$ & 49.5 & 56.5 & 53 & 1 & 10 \\
\hline 2 & $57-63$ & 56.5 & 63.5 & 60 & 2 & 23.33 \\
\hline 3 & $64-70$ & 63.5 & 70.5 & 67 & 11 & 36.67 \\
\hline 4 & $71-77$ & 70.5 & 77.5 & 74 & 7 & 16.67 \\
\hline 5 & $78-84$ & 77.5 & 84.5 & 81 & 6 & 10 \\
\hline \multirow[t]{2}{*}{6} & $85-91$ & 84.5 & 91.5 & 88 & 3 & 3.33 \\
\hline & & & & & 30 & 100 \\
\hline
\end{tabular}

Berdasarkan data dari Tabel 1. Distribusi frekuensi hasil belajar di kelas kontrol dapat ditunjukkan dalam bentuk histogram pada Gambar 1.

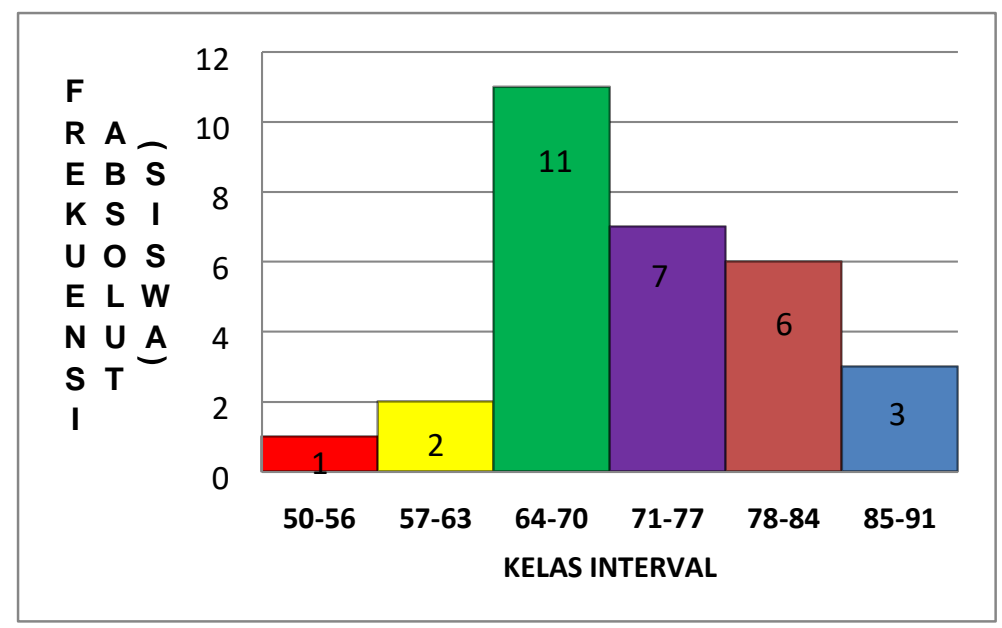

Gambar 1. Histogram Distribusi Frekuensi Kelas Kontrol.

Dari hasil analisis deskriptif kelas eksperimen terlihat bahwa, dari 30 peserta didik di kelas VIIb, total nilai hasil yang diperoleh 2625. Nilai tertinggi yang diperoleh 100. Nilai terendah yang diperoleh 60. Nilai rata-rata diperoleh 87.5. Standar deeviasi yang diperoleh 8.38. Varians yang diperoleh 70.25. Median/nilai tengah yang diperoleh 90. Modus/nilai 
yang sering keluar 90. Adapun distribusi frekuensi data hasil belajar peserta didik di kelas eksperimen dengan model pembelajaran yang menggunakan multimedia computer assistance instruction model tutorial ditampilkan pada Tabel 2.

Tabel 2. Distribusi Frekuensi Hasil Belajar Di Kelas Eksperimen

\begin{tabular}{|c|c|c|c|c|c|c|}
\hline \multicolumn{7}{|c|}{ REKAPITULASI FREKUENSI KELAS EKSPERIMEN } \\
\hline \multirow[b]{3}{*}{ NO } & \multicolumn{4}{|c|}{ BATAS NYATA } & \multicolumn{2}{|c|}{ FREKUENSI } \\
\hline & \multirow{2}{*}{$\begin{array}{c}\text { KELAS } \\
\text { INTERVAL }\end{array}$} & \multirow[b]{2}{*}{ ВАWAН } & \multirow[b]{2}{*}{ ATAS } & \multirow{2}{*}{$\begin{array}{c}\text { NILAI } \\
\text { TENGAH }\end{array}$} & & \\
\hline & & & & & $\begin{array}{c}\text { ABSOLUT } \\
\text { (SISWA) }\end{array}$ & $\begin{array}{c}\text { RELATIF } \\
(\%)\end{array}$ \\
\hline 1 & $60-66$ & 59.5 & 66.5 & 63 & 1 & 3.33 \\
\hline 2 & $67-73$ & 66.5 & 73.5 & 70 & 0 & 0.00 \\
\hline 3 & $74-80$ & 73.5 & 80.5 & 77 & 5 & 16.67 \\
\hline 4 & $81-87$ & 80.5 & 87.5 & 84 & 7 & 23.33 \\
\hline 5 & $88-94$ & 87.5 & 94.5 & 91 & 10 & 33.33 \\
\hline \multirow[t]{2}{*}{6} & $95-100$ & 94.5 & 100 & 98 & 7 & 23.33 \\
\hline & & & & & 30 & 100 \\
\hline
\end{tabular}

Berdasarkan data dari Tabel. 2 Distribusi frekuensi hasil belajar di kelas eksperimen diatas dapat ditunjukkan dalam bentuk histogram pada Gambar 2.

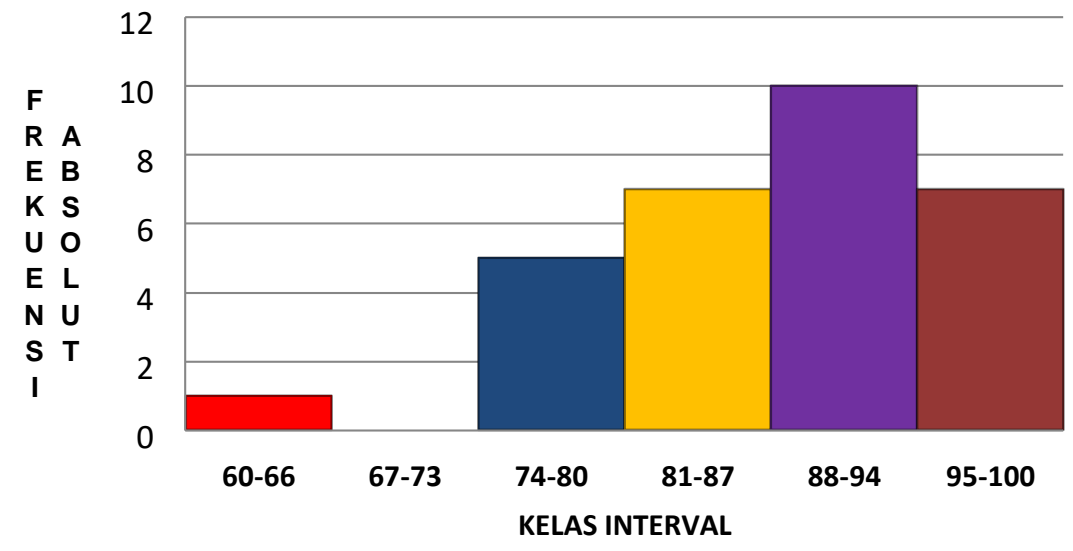

Gambar 2. Histogram Distribusi Frekuensi Pada Kelas Eksperimen

Pada Uji Validitas penulis menggunakan taraf $\alpha=0.05$ dan $n=30$ maka diperoleh $r_{\text {tabel }}=0.36$, berdasarkan kriteria bahwa $r_{\text {pbis }}>r_{\text {tabel }}$ maka dari 40 soal yang diuji, sebanyak 20 soal dinyatakan valid, dan yang tidak valid sebanyak 20 soal. Selanjutnya sebanyak 20 soal yang telah valid dilakukan uji reliabilitas dengan rumus KR 20 (Kuder Richardo) 
dengan nilai $\mathrm{Kr}$ 0.85. Berdasarkan tabel interprestasi reliabilitas, maka $\mathrm{Kr} 0.85$ termasuk kategori reliabilitas yang sangat tinggi.

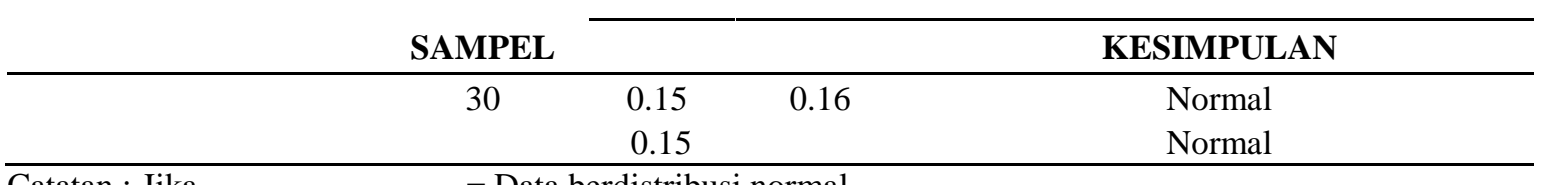

Catatan : Jika $=$ Data berdistribusi normal

Tabel 3. Rekapitulasi Hasil Perhitungan Uji Normalitas

\section{PERLAKUAN}

Kelas kontrol Kelas eksperimen 30
0.16

Berdasarkan hasil perhitungan uji normalitas menggunakan Uji Lilliefors, untuk

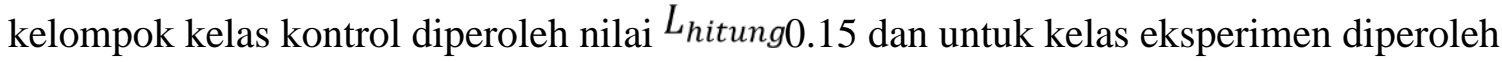
$L_{\text {hitung }} 0.15$. nilai kritis $L$ pada taraf signifikasi $\alpha=0.05$ sebesar 0.16 . karena $L_{\text {hitung }}$ untuk setiap kelompok lebih kecil dari $L_{\text {tabelmaka }} H_{0}$ diterima, berarti data dari kedua kelompok perlakuan berdistribusi normal dan uji dapat dilanjutkan untuk melihat homogenitas asal populasi kelompok data.

Uji Homogenitas

Uji homogenitas dilakukan untuk melihat apakah kedua kelompok sampel mempunyai varians yang homogen atau tidak. Berikut disajikan tabel analisis uji homogenitas dengan menggunakan uji kesamaan varians yaitu perbandingan antara varians terbesar dengan varians terkecil.

Tabel 4. Rekapitulasi Hasil Perhitungan Uji Homogenitas

\begin{tabular}{lcccccc}
\cline { 1 - 3 } \multicolumn{1}{c}{ PERLAKUAN } & VARIANS & F-hitung & F-tabel & & KESIMPULAN \\
\hline Kelas kontrol & 72.99 & 1.04 & 1.86 & & Homogen \\
Kelas eksperiment & 70.26 & & & & \\
\hline
\end{tabular}

Nilai diperoleh $F_{\text {hitung }}<F_{\text {tabel }}(1.04<1.86)$, maka dapat disimpulkan bahwa Varian data yang dianalisis adalah homogen. Analisis dilakukan dengan melakukan pengujian hipotesis dengan menggunakan uji beda (uji-t). uji-t dilakukan dengan membandingkan nilai rata-rata postes dari kedua kelompok penelitian.

Tabel 5. Rekapitulasi Hasil Perhitungan Uji t

\begin{tabular}{|c|c|c|c|c|c|}
\hline PERLAKUAN & SAMPEL & RATA-RATA & $\mathbf{T}_{\text {-hitung }}$ & $T_{\text {-tabel }}$ & KEPUTUSAI \\
\hline Kelas kontrol & 30 & 73.33 & & $\alpha=0.05$ & Tolak $\mathrm{H}_{\mathrm{O}}$ \\
\hline & & & 2.19 & $=1.69$ & \\
\hline
\end{tabular}


Berdasarkan perhitungan tersebut ternyata $t_{\text {hitung }}>t_{\text {tabel }}(2.19>1.69)$. Dengan demikian $H_{1}$ diterima. Jadi kesimpulannya terdapat pengaruh yang signifikan antara hasil belajar peserta didik pada sub pokok bahasan interaksi dalam ekosistem dengan menggunakan multimedia computer assistance instrution model tutorial di kelas VII SMP Kartini 2 Batam.

Computer Asisstance Instruction (CAI) yaitu penggunaan komputer secara langsung dengan peserta didik untuk menyampaikan isi pelajaran, memberikan latihan dan mengetes kemajuan belajar peserta didik. Berdasarkan hasil penelitian dengan penggunaan computer assistance instruction model tutorial dalam pembelajarannya dapat membantu peserta didik memahami suatu materi dan dapat mengulang materi tersebut berulang kali sampai ia menguasai materi itu.

Untuk memperkuat hipotesis dalam penelitian juga memberikan perlakuan kepada kedua kelas, yaitu kelas kontrol yang tanpa menggunakan multimedia computer assistance instruction model tutorial dalam pembelajarannya. Dan kelas eksperimen yang menggunakan multimedia computer assistance instruction model tutorial dalam pembelajarannya. Setelah perlakuan diberikan kepada kedua kelas maka kedua kelas diberikan postes pada hari yang sama dengan waktu yang berbeda. Dari data postes yang telah diperoleh maka didapat pada kelas eksperimen diperoleh rata-rata 87.5 dengan standar deviasi sebesar 8.38, sedangkan untuk peserta didik pada kelas kontrol diperoleh rata-rata sebesar 73.33 dengan standar deviasi sebesar 8.54. Pengujian hipotesis dengan Uji- t yang diperoleh dari rata-rata postes kelas eksperimen dan kelas kontrol maka diperoleh $t_{\text {hitung }}>$ $t_{\text {tabel }}(2.19>1.69)$. Sehingga $H_{1}$ diterima dan $H_{0}$ ditolak pada taraf $\alpha=0.05$. yang sekaigus berarti hasil belajar peserta didik yang menggunakan multimedia computer assistance instruction model tutorial dalam pembelajarannya lebih baik dari hasil belajar peserta didik yang tidak menggunakan multimedia computer assistance instruction model tutorial dalam pembelajarannya. Dengan demikian menunjukkan bahwa adanya pengaruh terhadap peningkatan hasil belajar peserta didiknya yang signifikan yang dalam proses pembelajarannya menggunakan multimedia interaktif. 


\section{KESIMPULAN}

Berdasarkan analisis tidak menggunakan multimedia computer assistance instruction model pembelajaran konvesional diperoleh rata-rata hasil belajar sebesar 73.33. sedangkan kelas eksperimen atau kelas yang dalam proses pembelajarannya menggunakan multimedia computer assistance instruction model tutorial, memperoleh rata-rata hasil belajar sebesar 87.5. Maka terdapat pengaruh peningkatan yang signifikan terhadap hasil belajar peserta didik

Pengujian hipotesis $t_{\text {hitung }}>t_{\text {tabel }}\left(2.19>1.69\right.$ ). Sehingga $H_{1}$ diterima dan $H_{0}$ ditolak dapat disimpulkan bahwa penggunaan multimedia computer assistance instruction model tutorial dalam proses pembelajaran dapat meningkatkan hasil belajar peserta didik

\section{REFERENSI}

Darmawan D. 2012. Teknologi pembelajaran. PT Remaja Rosdakarya. Bandung.

Indriana. 2011. Ragam alat bantu media pelajaran. Diva Press. Jogjakarta.

Kadek. 2010. Multimedia modern. Raja Grafindo Persada. Jakarta.

Mardika. 2012. Inovasi pendidikan. Alfabeta. Bandung.

Musfiqon. 2012. Pengembangan media dan sumber pembelajaran. Prestasi Pustaka. Jakarta.

Salminda, L., Ramses, R., Efendi, Y. (2015). Pengaruh Model Pembelajaran Terbalik (Reciprocal Teaching) Menggunakan Buku Saku Terhadap Hasil Belajar Biologi Siswa Kelas VII MTs USB Sagulung Batam. SIMBIOSA, 4(1).

Sanjaya W. 2008. Perencanaan dan desain sistem belajar. Kencana Prenada Media Group. Jakarta.

Suartama. 2010. Pendidikan sekarang dan nanti. Bumi aksara. Jakarta.

Sudjana. 2005. Penilaian hasil proses belajar mengajar. Remaja Rosdakarya. Bandung.

Sugiyono.2009. Panduan Modern Penelitian Kuantitatif. Alfabeta. Bandung.

Smaldino S. 2011. Instruction technology \& media for learning. Kencana Prenada Media Group. Jakarta. 